\title{
Animal Model
}

\section{$\mathrm{CD} 4^{+} \mathrm{CD} 25^{+}$Regulatory T Lymphocytes Inhibit Microbially Induced Colon Cancer in Rag2-Deficient Mice}

\author{
Susan E. Erdman, ${ }^{*}$ Theofilos Poutahidis, ${ }^{*}$ \\ Michal Tomczak, ${ }^{\dagger}$ Arlin B. Rogers, ${ }^{*}$ \\ Kathleen Cormier, ${ }^{*}$ Benjamin Plank, ${ }^{\dagger}$ \\ Bruce H. Horwitz, ${ }^{\dagger \neq}$ and James G. Fox* \\ From the Division of Comparative Medicine,* Massachusetts \\ Institute of Technology, Cambridge; the Department of \\ Pathology, ${ }^{\dagger}$ Immunology Research Division, Brigham and \\ Women's Hospital, Boston; and the Division of Emergency \\ Medicine, ${ }^{\ddagger}$ Children's Hospital, Boston, Massachusetts
}

Inflammatory bowel diseases, including ulcerative colitis and Crohn's disease, increase the risk of colorectal cancer in humans. It has been recently shown in humans and animal models that intestinal microbiota and host immunity are integral in the progression of large bowel diseases. Lymphocytes are widely believed to prevent bacterially induced inflammation in the bowel, and lymphocytes are also critical in protecting against primary tumors of intestinal epithelia in mice. Taken together, this raises the possibility that lymphocytes may inhibit colon carcinogenesis by reducing bacterially driven inflammation. To examine the role of bacteria, lymphocytes, and inflammatory bowel disease in the development of colon cancer, 129/SvEv Rag-2-deficient and congenic wildtype mice were orally inoculated with a widespread enteric mouse bacterial pathogen, Helicobacter bepaticus, or sham-dosed with media only. $H$. bepaticus-infected Rag2-/-, but not sham-dosed Rag2-/mice, rapidly developed colitis and large bowel carcinoma. This demonstrated a link between microbially driven inflammation and cancer in the lower bowel and suggested that innate immune dysregulation may have an important role in inflammatory bowel disease and progression to cancer. $\boldsymbol{H}$. bepaticus-infected wild-type mice did not develop inflammation or carcinoma showing that lymphocytes were required to prevent bacterially induced cancer at this site. Adoptive transfer with $\mathrm{CD}^{+} \mathrm{CD}^{+} 5 \mathrm{RB}^{10} \mathrm{CD} 25^{+}$regulatory $\mathrm{T}$ cells into Rag-deficient hosts significantly inhibited $H$. bepaticus-induced inflammation and development of cancer. These results suggested that the ability of $\mathrm{CD}^{+} \mathrm{T}$ cells to protect against intestinal cancer was correlated with their ability to reduce bacterially induced inflammatory bowel disease. Further, regulatory $T$ cells may act directly on the innate immune system to reduce or prevent disease. These roles for $T$ cells in protection against colon carcinoma may have implications for new modes of prevention and treatment of cancer in humans. (Am J Patbol 2003, 162:691-702)

In humans with inflammatory bowel disease (IBD), colon cancer arises from dysplastic epithelial foci. ${ }^{1-3}$ Many factors contribute to inflammatory and neoplastic diseases of the lower bowel, but clinical trials using antibiotics, probiotics, and cytokines have shown that microbial status and host immunity are pivotal in progression of lower bowel disease. ${ }^{4}$ A bacterial etiology of tumorigenesis has not yet been established in the colon of humans; however, gastric carcinoma in humans has been convincingly linked with chronic Helicobacter pylori-induced inflammation. ${ }^{5-7}$

Adaptive immunity has been proven critical in protection against intestinal cancer. Shankaran and colleagues $^{8}$ showed that mice lacking functional lymphocytes had a markedly higher frequency of lower bowel carcinoma compared with congenic wild-type mice. It was suggested that lymphocytes prevented cancer primarily by detecting and eliminating newly arising tumors., ${ }^{8,9}$ Lymphocytes, however, are also proposed to have a critical role in regulating bacterially induced inflammation in the lower bowel. ${ }^{10-14}$ This raises the possibility that modulation of inflammatory responses to enteric bacteria may influence progression of cancer in the

Supported by the National Institutes of Health (grants R01CA67529 and R01Al50952 to J. G. F.) and a Crohn's and Colitis Foundation Award (to B. H. H. and S. E. E.).

Accepted for publication October 17, 2002.

Address reprint requests to Susan E. Erdman, Division of Comparative Medicine, Massachusetts Institute of Technology, 77 Massachusetts Ave., Cambridge, MA 02139. E-mail: serdman@mit.edu. 
intestine. Indeed, enteric bacteria were required for lower bowel adenocarcinoma to develop in germ-free TCR $\beta$ deficient mice, ${ }^{15}$ and bacterial infection increased severity of cancer in $A p c^{\mathrm{min} /+}$ mice. ${ }^{16}$

Recombinase-activating gene (Rag)-1- or -2-deficient mice lack functional lymphocytes because of an inability to properly rearrange antigen receptors. ${ }^{17}$ The absence of functional $\mathrm{T}$ and $\mathrm{B}$ cells, and the ability to transfer specified subsets of lymphocytes from immunocompetent mice, make this mouse a valuable model to study innate and adaptive immunity in the lower bowel. Ragdeficient mice have been used extensively as a host in adoptive transfer studies of colitis induced by $\mathrm{CD}^{+}{ }^{+} \mathrm{CD} 45 \mathrm{RB}^{\text {hi }} \mathrm{T}$ cells. The role of $\mathrm{T}$ cells in induction of IBD has been widely studied; ${ }^{18,19}$ however, $T$ cells are not absolutely required for chronic inflammation in the colon. ${ }^{11,20}$ Colitis in SCID and Rag-deficient mice could be induced by infection with a widespread enteric mouse bacterial pathogen, Helicobacter hepaticus, without the need for effector T lymphocytes. ${ }^{11,21}$

Colitis induced by the transfer of $\mathrm{CD}^{+}$effector T cells is preventable by co-transfer of $\mathrm{CD}^{+} \mathrm{CD}^{+} \mathrm{RB} \mathrm{B}^{\mathrm{lo}}$ or $\mathrm{CD}^{+}{ }^{+} \mathrm{CD} 25^{+}$regulatory $\mathrm{T}$ cells. ${ }^{10,18,19,22,23}$ These $\mathrm{T}$ cells, which are distinguished from their counterparts by cytokine profile and tolerance induction, were first recognized for their ability to prevent autoimmune disease in rodents. ${ }^{19,24}$ Later, CD4 ${ }^{+} \mathrm{CD} 25^{+}$cells with similar functions were isolated from thymus and peripheral blood of humans. ${ }^{19,25,26}$ The regulatory cells that inhibit intestinal inflammation are believed to be found predominantly in the $\mathrm{CD}^{+}{ }^{+} \mathrm{CD}_{45 \mathrm{RB}^{\mathrm{lo}}} \mathrm{CD}^{2} 5^{+}$population of cells. ${ }^{19,27,28}$

Given that $H$. pylori-induced chronic inflammation leads to gastric carcinoma in humans and mice, 5,29 we postulated that certain bacteria may similarly induce inflammation-associated cancer in the lower bowel. Based on evidence that lymphocytes were critical to preventing intestinal cancer, and that $\mathrm{CD}^{+}{ }^{+} \mathrm{CD}_{4}$ RB ${ }^{\mathrm{lo}} \mathrm{CD}^{2} 5^{+} \mathrm{T}$ lymphocytes regulate inflammation in the lower bowel of mice, we hypothesized that these $T$ cells may inhibit cancer by suppressing chronic microbially induced inflammation in the lower bowel. Inability to inhibit bacterially driven inflammation might explain the high frequency of lower bowel adenocarcinoma observed in Rag-deficient mice. Thus, we examined progression of $H$. hepaticus-induced inflammation and cancer in Rag-2-deficient mice, with and without adoptive transfer of $\mathrm{CD}_{4}^{+}$ CD45RB ${ }^{\text {lo }} \mathrm{CD}^{+} 5^{+}$T lymphocytes.

\section{Materials and Methods}

\section{Rag2 Mice Were Housed in a Helicobacter-Free Mouse Facility}

All mice were housed in Association for Assessment and Accreditation of Laboratory Animal Care-approved facilities in static microisolator cages. 129/SvEv Rag2-deficient mice from Taconic Farms (Germantown, NY) were housed for 18 months with health status free of known murine viruses, Salmonella spp, Citrobacter rodentium, ecto- and endoparasites, and known murine Helicobacter spp. A Rag2-deficient breeding colony was established in this facility to provide mice for subsequent infection experiments.

\section{Experimental Infection}

H. hepaticus (strain 3B1, no. 51449; American Type Culture Collection, Rockville, MD) was grown as described elsewhere. ${ }^{30}$ Cultures were examined by Gram's stain and phase microscopy for contaminants and subcultured on blood agar to confirm purity. Bacteria were resuspended in brucella broth at $10^{8}$ bacteria/ml as confirmed by spectrophotometry. ${ }^{31}$ Experimental mice received 0.2 $\mathrm{ml}$ of fresh inoculum by gastric gavage every other day for three doses.

At age 6 to 8 weeks, helicobacter-free Rag-2-deficient mice were dosed with $H$. hepaticus suspended in broth or sham-dosed with broth only. A cohort of aging 129/SvEv Rag-2-deficient mice remained untreated. The infected and control uninfected mice were housed in microisolator caging in different areas within the animal facility. Replicate experiments were conducted with three groups of similar size. In each experiment, half of the mice were male and half of the mice were female.

\section{Confirmation of $\mathrm{H}$. hepaticus Infection}

Cecum and colon were collected at necropsy and analyzed by polymerase chain reaction to confirm experimental infection using $H$. hepaticus-specific primers. ${ }^{32}$ Helicobacter-free status was confirmed in controls using polymerase chain reaction with helicobacter genus-specific primers. $^{33}$

\section{Adoptive Transfer of T Cells in Rag-2 Knockout Mice}

To examine whether $T$ cells modulate progression of cancer in $\mathrm{H}$. hepaticus-infected Rag2 mice, we performed transfers of purified (as below) T lymphocytes from helicobacter-free 129/SvEv donors into Rag2-deficient mice. Half of the lymphocyte donors were male and half of the donors were female.

Before experimental $H$. hepaticus infection, anesthetized mice were injected intravenously in the retro-orbital sinus with $2 \times 10^{5} \mathrm{~T}$ cells suspended in $0.2 \mathrm{ml}$ of media using a 26-gauge needle. Mice were dosed 72 hours later with $H$. hepaticus, as described above.

\section{Purification of T Cells for Adoptive Transfer}

To obtain viable and highly purified populations of $T$ cells for adoptive transfer, single cell suspensions from spleen and mesenteric lymph nodes from helicobacter-free 129/ SvEv mice were prepared. CD4-positive cells were isolated by using L3T4 Dynabeads (Dynal, Oslo, Norway). Cells were detached from the beads using mouse CD4 DETACHaBEAD (Dynal). The purity of $\mathrm{CD}^{+}$cells isolated in this manner was $>95 \%$. CD $45 \mathrm{RB}^{\text {lo }} \mathrm{CD}^{2} 5^{+}$cells 
were further isolated from the $\mathrm{CD}^{+}$population by labeling with anti-CD45RB-FITC antibodies (Pharmingen, La Jolla, CA) and anti-CD25-PE antibodies (Pharmingen) and then purified by flow cytometry. Purified cells were resuspended in RPMI with 10\% fetal calf serum before injection as previously described. ${ }^{34}$ Reanalysis of these cells before transfer into mice indicated that purity was $>99 \%$.

\section{Confirmation of Adoptive Transfer of CD45RB ${ }^{\prime o}$ CD25 ${ }^{+}$Cells}

Host spleens were collected at the time of necropsy, and single cell suspensions were prepared. Cells were stained with anti-CD3 and anti-CD4 antibodies and analyzed by flow cytometry. The percentage of $\mathrm{CD}^{+} \mathrm{CD}^{+}$ cells in the spleens of these animals ranged from 0 to $7 \%$. $\mathrm{CD}^{+}{ }^{+} \mathrm{CD} 4^{+} \mathrm{T}$ cells made up less than $1 \%$ of the splenocytes in 3 of the 17 mice that received $\mathrm{CD} 4^{+} \mathrm{CD} 45 \mathrm{RB}^{\text {lo }}$ $\mathrm{CD}^{2} 5^{+}$cells. One ( 1 of 17 ) mouse had no evidence of $\mathrm{CD} 4^{+}$cells in the spleen on necropsy.

\section{Histological Evaluation}

Formalin-fixed tissues were embedded in paraffin, cut at $5 \mu \mathrm{m}$, and stained with hematoxylin and eosin. Lesions were scored by a pathologist blinded to sample identity. The cecal and colonic lesions were scored on the basis of size and frequency of hyperplastic and inflammatory lesions on a scale of 0 to 4 with ascending severity $(0$, none; 1, minimal; 2, mild; 3, moderate; and 4, severe) modified from Berg and colleagues. ${ }^{35}$ Epithelial dysplasia and neoplasia were graded using a scale of 0 to 4 based on a recently described scheme: ${ }^{36-38}$ grade 0 , normal (Figure 1; A to C); 1, mild dysplastic changes (Figure 1; D to F); 2, low-grade adenoma/dysplasia (Figure 1; G to I); 3, high-grade adenoma/dysplasia, carcinoma in situ, or intramucosal carcinoma (Figure 1, $\mathrm{J}$ to O; Figure 2, A and B; Figure 3A); and 4, invasive carcinoma (Figure 4; $A$ to $C$ ). Figures 1 and 2 show the grading system and depict the spectrum of dysplastic and neoplastic lesions observed in this study. Data are compiled from three replicate experiments with statistically similar results. Nonparametric data are presented as median score and range (in parentheses) for each group.

\section{Immunohistochemical Assessment of Epithelial Proliferation or Tumor Invasion}

Cell proliferation and invasion were determined using monoclonal antibodies directed against Ki-67 (BD Biosciences, San Diego, CA), and pan-cytokeratin (AE1/ AE3; DAKO, Carpinteria, CA), respectively. Standard immunohistochemistry was performed on an $i 6000$ autostainer (Biogenex, San Ramon, CA). Briefly, formalinfixed tissues on positively charged slides were deparaffinized and rehydrated. Antigen retrieval was performed with microwave heat in $\mathrm{pH} 6$ citrate buffer (DAKO) for $\mathrm{Ki}-67$, or with 5 minutes of protease digestion at $37^{\circ} \mathrm{C}$ using $10 \mathrm{mg} / \mathrm{ml}$ of proteinase K (Roche Molecular Systems, Indianapolis, IN) for cytokeratin. Endogenous peroxidases were quenched with two rounds of $3 \% \mathrm{H}_{2} \mathrm{O}_{2}$ in phosphate-buffered saline for 5 minutes each. For immunohistochemistry the ARK kit (DAKO) was used. Signal was detected with diaminobenzidine and tissues were counterstained with Gill's hematoxylin.

\section{Detection of Cytokine mRNA Expression in Cecum and Colon}

One-cm segments of cecum and colon near the junction were harvested immediately after mice were euthanized and the segments were snap-frozen in liquid nitrogen. Frozen specimens were homogenized into Tri-reagent (Molecular Research Center, Cincinnati, $\mathrm{OH}$ ) and RNA prepared per the manufacturer's instructions. RNase protection analyses were performed on $20 \mu \mathrm{g}$ of total RNA using RiboQuant Multi-Probe Template Sets (Pharmingen). Intensities of the protected fragments were quantitated by phosphorimager analysis and each cytokine was normalized to GAPDH internal controls.

\section{Statistical Analyses}

Analyses of cecal and colonic lesion scores were performed using a Mann-Whitney $U$ nonparametric test for ordinal data. Cytokine data were analyzed using a twotailed $t$-test.

\section{Results}

\section{Untreated Rag2-Deficient Mice Did Not Develop IBD or Cancer}

To determine whether enteric microbial status influenced frequency or distribution of lower bowel cancer in Ragdeficient mice, we first examined unmanipulated helicobacter-free Rag-2-deficient mice. Uninfected 129/SvEV Rag-2-knockout mice examined at 12 months of age ( $n=$ $16)$ and 15 months of age $(n=10)$ had no or minimal inflammation in the cecum [0 (0 to 0$)$ ] or colon [0 (0 to 1)], no epithelial hyperplasia in the cecum [0 (0 to 0$)]$ or colon [0 ( 0 to 0$)$ ], and no dysplasia or cancer in the cecum [0 (0 to 0$)$ ] or colon [0 (0 to 0$)$ ].

\section{$\mathrm{H}$. hepaticus-Induced IBD in Rag2-Deficient Mice}

To evaluate the ability of $H$. hepaticus to induce bowel lesions in Rag-2-deficient mice, mice were dosed with $H$. hepaticus and examined for histological changes in the cecum and colon. In H. hepaticus-infected Rag-2-deficient mice, there was significantly increased epithelial hyperplasia in the cecum [4 (3 to 4); $P=0.0001]$ and colon [4 (2 to 4); $P=0.0001]$ associated with inflammation in the cecum [4 (3 to 4); $P=0.0001$ ] and colon [4 (2 to 4 ); $P=0.0001$ ] (Figure 3 ; $A$ to $D$ ) compared with 


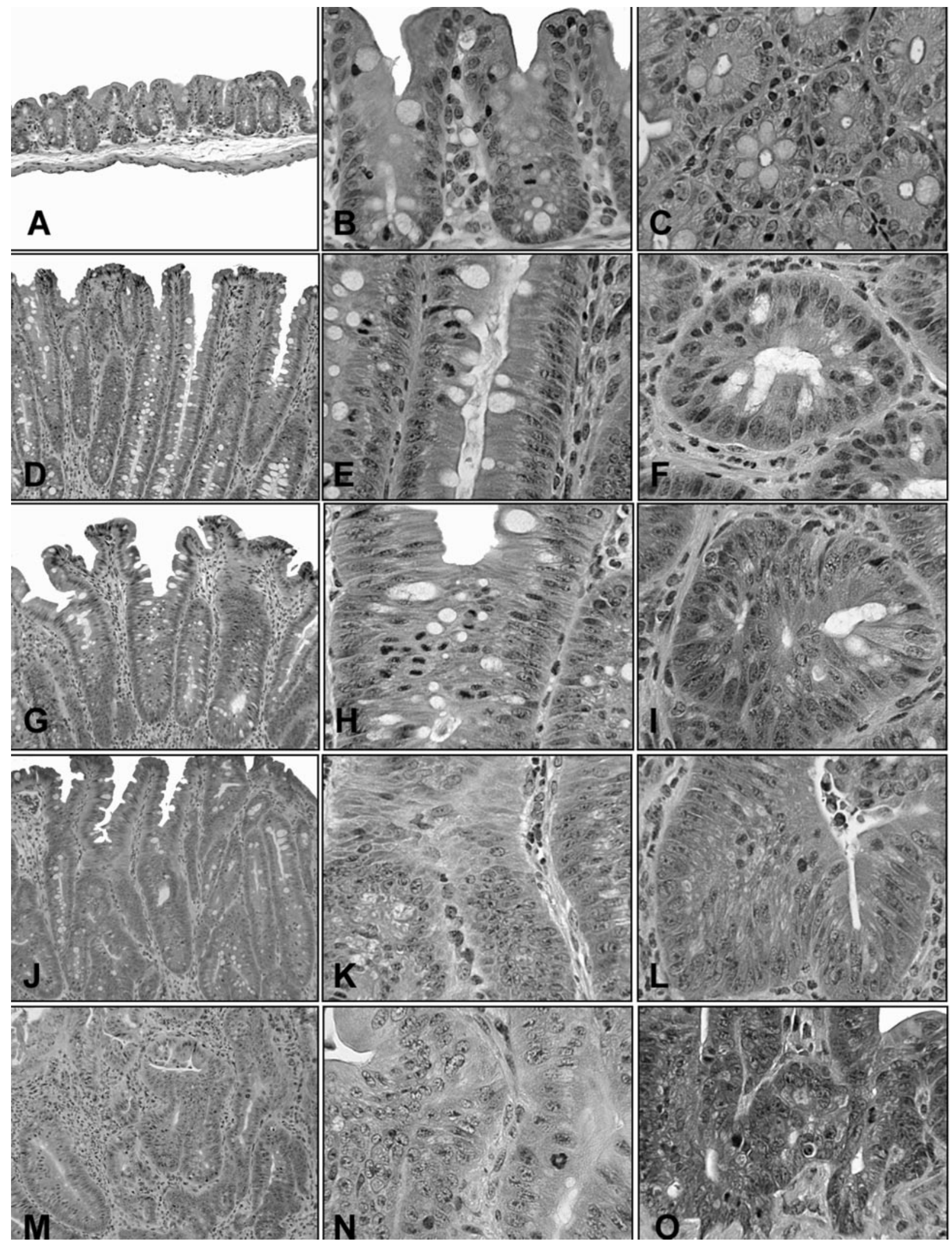

Figure 1. Large bowel histopathology depicting grades of dysplasia and neoplasia. Each row represents tissue from a single animal. The left panel in each row is a low-magnification view of mucosa. The middle and right panels are higher magnifications of the longitudinally sectioned and cross-sectioned glands, respectively. A-C: Uninfected control mouse. Remaining rows demonstrate progressively severe hyperplasia, dysplasia, and/or neoplasia from $H$. hepaticusinfected Rag-2-deficient mice. Note progressively increased severity of glandular and cellular atypia from the top to the bottom of each column. D-F: Mild dysplasia, grade 1. G-I: Low-grade adenoma and dysplasia, grade 2. J-L: High-grade adenoma and dysplasia, grade 3. M-O: Carcinoma in situ, grade 3. H\&E, original magnifications: $\times 100(\mathbf{A}, \mathbf{D}, \mathbf{G}, \mathbf{J}, \mathbf{M}) ; \times 400(\mathbf{B}, \mathbf{C}, \mathbf{E}, \mathbf{F}, \mathbf{H}, \mathbf{I}, \mathbf{K}, \mathbf{L}, \mathbf{N}, \mathbf{O})$ 

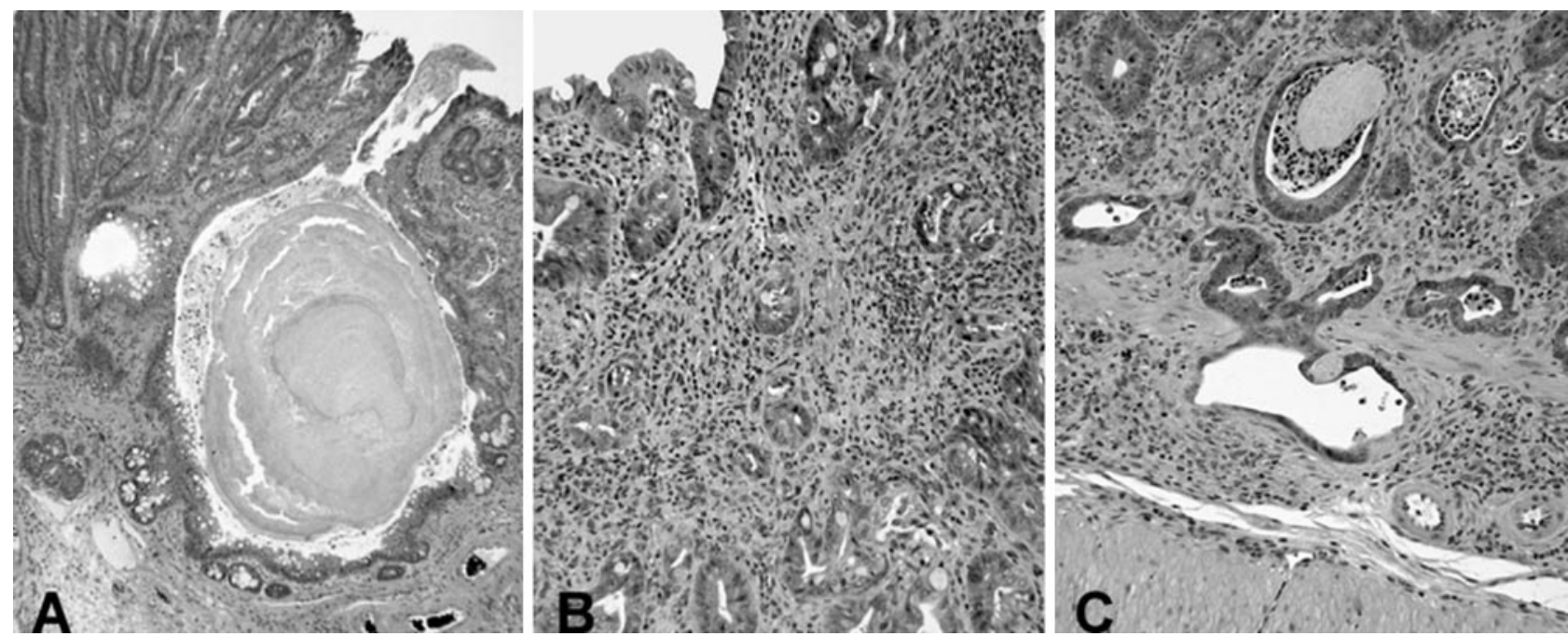

Figure 2. Histopathological features of dysplasia and carcinoma including a mucinous cyst lined by highly dysplastic epithelium (A), intramucosal carcinoma (B), and submucosal invasion $(\mathbf{C})$. Original magnifications: $\times 40(\mathbf{A}), \times 100(\mathbf{B}, \mathbf{C})$.

uninfected controls (Table 1). Figure 3 demonstrates the contrast between inflammation and hyperplasia in $\mathrm{H}$. hepaticus-infected and uninfected Rag-deficient mice. Inflammation was most severe in the lamina propria, with extension into the submucosa in advanced cases, and was comprised chiefly of macrophages and granulocytes. Macrophages and eosinophils predominated in approximately equal numbers, whereas neutrophils were less frequent and associated primarily with microabscessation (Figure 3C, inset). The hyperplastic changes were characterized by mild to marked elongation and thickness of the colonic crypts (Figure 1D, Figure 3C), epithelial hypercellularity, and increased numbers of mitotic figures per high-power field.

To correlate infection and inflammation with increased epithelial proliferation in these mice, Ki-67, a nuclear antigen expressed only during mitosis, was examined in lower bowel tissues from $H$. hepaticus-infected mice with $H$. hepaticus-induced inflammation and hyperplasia. Ki-67 staining was evident in cells of the superficial mucosa as well as in the base of the crypts in $\mathrm{H}$. hepaticusinfected mice, compared with the base of the crypts only in uninfected mice (Figure 4, D and E), suggesting dysregulation of epithelial proliferation.

\section{Rag2-Deficient Mice Were Highly Susceptible to H. hepaticus-Induced Epithelial Dysplasia and Cancer}

To determine whether $H$. hepaticus-associated bowel inflammation increased frequency of neoplasia in 129/SvEv Rag2-deficient mice, $H$. hepaticus-infected Rag-2-deficient mice were examined for epithelial changes at 2, 4, and 8 months after infection. Figures 2 to 4 depict the spectrum of dysplastic and neoplastic lower bowel epithelial lesions in $H$. hepaticus-infected mice. Dysplasia of the crypt epithelium was evidenced by loss of goblet cells, pseudostratification, loss of nuclear polarity, nu- clear atypia, and cell pleomorphism. Some cells were elongated with basophilic cytoplasm and heterochromatic nuclei whereas others had amphophilic cytoplasm and rounded, variably sized, euchromatic nuclei with prominent nucleoli. Irregularities of crypt architecture included tortuosity, branching, variability in shape and size, slit-shaped lumens, and cystic dilatation (Figure 1, $\mathrm{D}$ to $\mathrm{O}$; Figure 3A). Occasional dilated crypts occupied the full length of the mucosa and were filled with mucous and lined by highly dysplastic epithelium (Figure 4A). Rarely, the surface epithelium formed papillary projections. Small sessile tubular adenomas (Figure 5C) were seen but there were no pendunculated or villus adenomas. Noninvasive carcinoma (carcinoma in situ) was very common (Figure 1; $\mathrm{M}$ to $\mathrm{O}$ ). The glands in these cases were severely dysplastic, irregular and branching without evident invasion into the muscularis mucosae. Intramucosal carcinoma, with extension into the lamina propria but not submucosa, was also observed (Figure 2B). There was trabecular growth and budding of glands, small-sized atypical glands, micronests, and single neoplastic cells invading the submucosa (Figure 4G).

Rag-2-deficient mice dosed with $H$. hepaticus also developed adenocarcinoma with muscle invasion in the colon within 60 days after infection (Figure 4, B and C). Adenocarcinomas invading the submucosa or the tunica muscularis seemed to arise from the ingrowth of the highly dysplastic deep epithelium. Variably sized, irregular dysplastic glands invaded through the muscularis mucosa into the submucosa and tunica muscularis. Neoplastic glands were generally well differentiated (Figure $4 \mathrm{~A}$ ) but some glands were highly irregular (Figure 3C) and occasional cystic spaces contained mucin pools (Figure 4, B and C). Either grade 3 (without invasion) or grade 4 (with invasion) carcinoma was observed in all (12 of 12) of the mice at 4 months after infection (Table 1). $H$. hepaticus-induced cancer was more frequent in the cecum initially, but comparable in cecum and colon at 6 


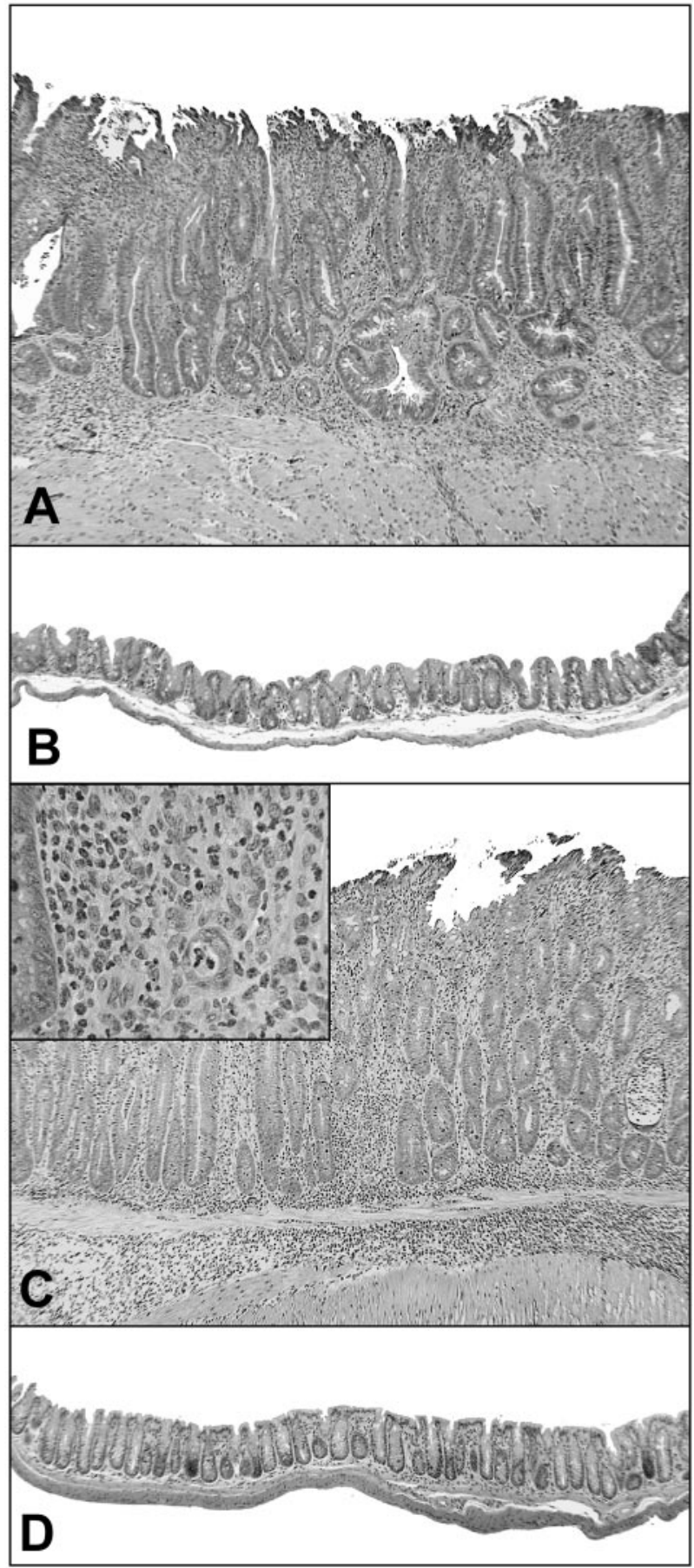

Figure 3. H. hepaticus-induced severe typhlitis (A) and colitis (C) in Rag2-deficient mice at 2 months after infection. There is severe mucosal and submucosal inflammation, marked epithelial hyperplasia, loss of goblet cells, and surface epithelial cell necrosis and erosions. Note the irregularities of crypt architecture in $\mathbf{A}$ (tortuosity, branching, cystic dilatation) indicative of dysplasia. The inset depicts the mixed inflammatory cells including predominantly macrophages and eosinophils. Normal histology of cecum (B) and colon (D) from uninfected Rag-2-deficient mice at 12 months after infection. H\&E; original magnifications, $\times 400$.

months after infection. Mice with cancer had rectal prolapses but maintained body condition at 8 months after infection. Cytokeratin staining revealed no metastases in local lymph nodes in 10 mice examined.

\section{H. hepaticus-Infected Wild-Type Mice Had Minimal IBD and No Cancer}

To evaluate the role of lymphocytes in preventing pathology observed in $\mathrm{H}$. hepaticus-infected Rag-2-deficient mice, we first compared helicobacter-infected Rag-deficient versus congenic wild-type mice. $H$. hepaticus-infected 129/SvEv wild-type mice examined at 2 to 3 months after infection $(n=10)$ had no inflammation in the cecum [0 (0 to 0)] or colon [0 (0 to 0)], no epithelial hyperplasia in the cecum [0 (0 to 0)] or colon [0 (0 to 0)], and no dysplasia or cancer in the cecum [0 (0 to 0$)]$ or colon [0 (0 to 0)]. H. hepaticus-infected 129/SvEv wildtype mice examined at 6 to 8 months after infection $(n=$ 10) had minimal inflammation in the cecum [0.5 (0 to 1$)]$ or colon [0 .5 (0 to 1)], minimal epithelial hyperplasia in the cecum [0 (0 to 1$)]$ or colon [0 (0 to 1$)]$, and no dysplasia or neoplasia in the cecum [0 (0 to 0)] or colon [0 (0 to 0)]. These findings supported the critical role of lymphocytes in protection against colon cancer in this model and led us to examine whether lymphocyte subsets known to suppress intestinal inflammation may help protect against development of cancer.

\section{CD4 ${ }^{+}$CD45RB ${ }^{\prime 0}$ CD25 ${ }^{+}$Regulatory T Cells Inhibited Development of $\mathrm{H}$. hepaticus-Induced Typhlocolitis and Cancer in Rag-2-Deficient Mice}

To examine whether CD4 ${ }^{+}$T cells that suppressed colitis in other models may also suppress development of microbially induced colon cancer in Rag-2-deficient mice, we performed adoptive transfer of T cells. Adoptive transfer of purified $\mathrm{CD} 4{ }^{+} \mathrm{CD}_{45 \mathrm{RB}}{ }^{\mathrm{lo}} \mathrm{CD} 5^{+}$cells $(n=17), 72$ hours before infection with $H$. hepaticus, significantly blocked development of inflammation [2 (0 to 4); $P<$ 0.0001 ] and hyperplasia [1 (0 to 4); $P<0.0001$ ] in cecum, and inflammation [2 (0 to 4); $P<0.0001$ ] and hyperplasia [1 (0 to 4); $P<0.0001$ ] in colon. Adoptive transfer also inhibited dysplasia and neoplasia in the cecum [1 (0 to 4); $P<0.001$ ] and the colon [0 (0 to 4); $P<0.001]$, when analyzed at 3 months after infection with $H$. hepaticus (Table 2 and Figure 5). Seven of 17 of the lymphocyte recipients had no evidence of inflammation (score $=0$ ) or dysplasia (score $=0$ ) in the cecum or colon, and 4 of 17 mice had minimal or mild inflammation (score $\leq 2$ ) but no dysplasia. Six of 17 recipients had localized moderate or severe inflammation and epithelial dysplasia in the cecum and colon. Figure 5 demonstrates the ability of $\mathrm{CD}^{+}{ }^{+} \mathrm{CD} 45 \mathrm{RB}^{\mathrm{lo}} \mathrm{CD}^{2} 5^{+} \mathrm{T}$ cells to inhibit development of $H$. hepaticus-induced inflammation and dysplasia. Furthermore, there was a significant reduction in the expression of mRNA for proinflammatory cytokine interleukin (IL)-12, tumor necrosis factor- $\alpha$, and IP-10 in the cecum of mice that received $\mathrm{CD} 4^{+} \mathrm{CD}_{45 \mathrm{RB}}{ }^{\mathrm{lo}} \mathrm{CD} 25^{+}$ T cells before $H$. hepaticus infection, compared with Ragdeficient mice that did not receive $T$ lymphocytes before infection (Figure 6). There were small but statistically significant increases in the Th2-like cytokines IL-10 and 

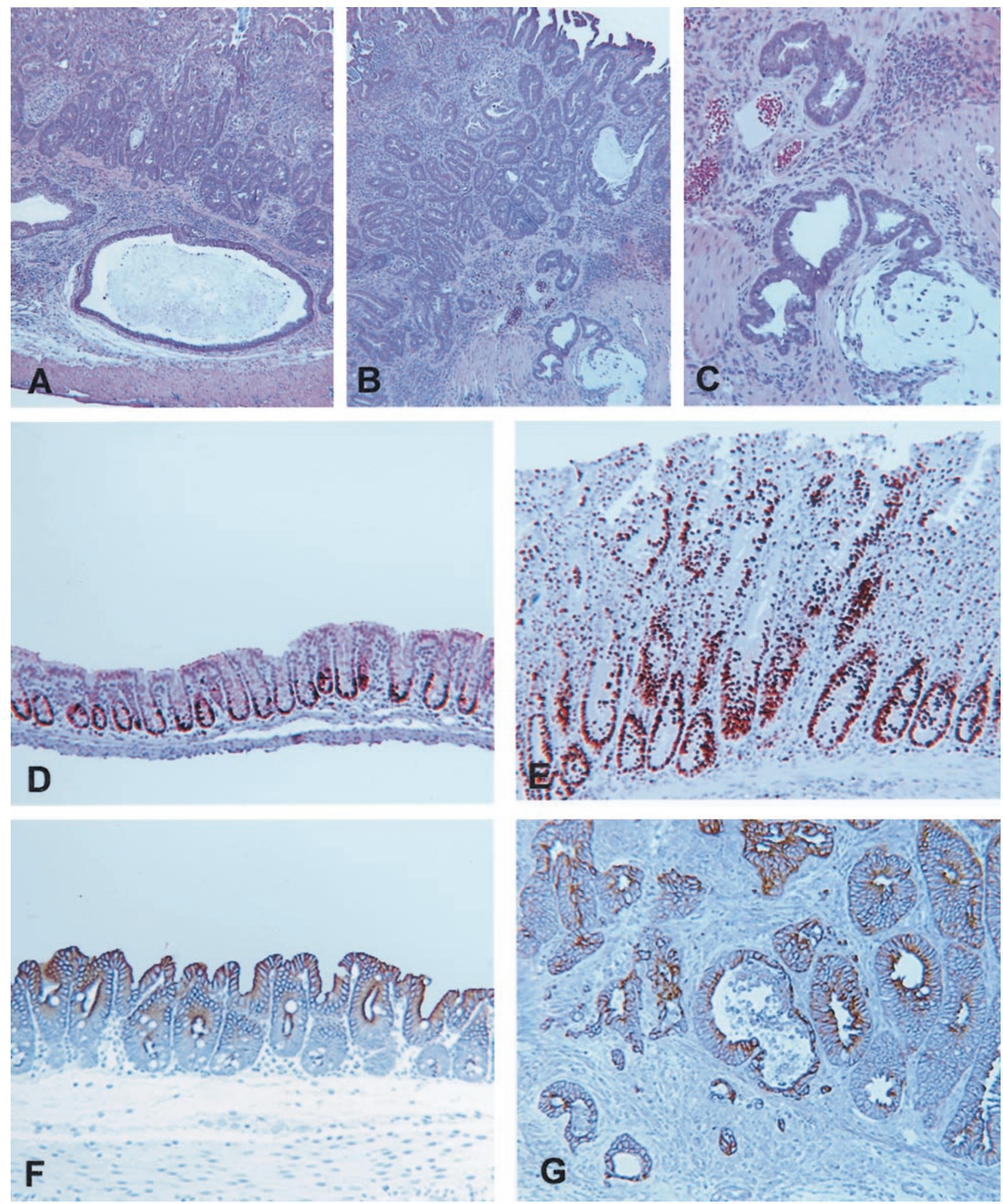

Figure 4. Invasive adenocarcinoma of cecum (A) and colon (B and C), H\&E. A: Well-differentiated neoplastic glands invaded into the submucosa. B: Invasive adenocarcinoma arising in an area of severe colitis and dysplasia. $\mathbf{C}$ : Higher magnification of the carcinoma illustrated in $\mathbf{B}$, demonstrating invasion into the muscle layer; note the irregular shape of malignant glands and a mucin pool. Immunohistochemical staining of colon (D, E) and cecum (F, G) of uninfected (D, F) and H. hepaticus-infected $(\mathbf{E}, \mathbf{G})$ Rag-2-deficient mice for Ki-67 (D, E), and cytokeratins (F, G). Diaminobenzidine, Gill's hematoxylin counterstain. E: Increased proliferative activity and expansion of the crypt proliferative zone toward the surface epithelium. G: Cytokeratin immunolabeling highlights the presence of small nests and single epithelial cells invading into the lamina propria and submucosa. Original magnifications: $\times 40(\mathbf{A}, \mathbf{B}, \mathbf{C}, \mathbf{D}, \mathbf{E}, \mathbf{F}, \mathbf{G}) ; \times 100(\mathbf{H}, \mathbf{I})$ 
Table 1. Comparison of Bowel Disease in H. hepaticus-Infected and Uninfected Rag-2-Deficient Mice

\begin{tabular}{|c|c|c|c|c|c|c|c|}
\hline & \multicolumn{2}{|c|}{$\begin{array}{c}\text { H. hepaticus-free } \\
\text { Rag2-deficient (controls) }\end{array}$} & \multicolumn{5}{|c|}{ H. hepaticus-infected Rag2-deficient } \\
\hline & $\begin{array}{c}2 \text { months } \\
\text { post-dose } \\
n=12 \\
\text { score } \\
\text { (range) }\end{array}$ & $\begin{array}{c}6 \text { months } \\
\text { post-dose } \\
n=7 \\
\text { score } \\
\text { (range) }\end{array}$ & $\begin{array}{c}1 \text { month PI } \\
n=8 \\
\text { score } \\
\text { (range) }\end{array}$ & $\begin{array}{c}2 \text { months PI } \\
n=16 \\
\text { score } \\
\text { (range) }\end{array}$ & $\begin{array}{c}4 \text { months PI } \\
n=12 \\
\text { score } \\
\text { (range) }\end{array}$ & $\begin{array}{c}6 \text { months PI } \\
n=17 \\
\text { score } \\
\text { (range) }\end{array}$ & $\begin{array}{c}8 \text { months PI } \\
n=12 \\
\text { score } \\
\text { (range) }\end{array}$ \\
\hline \multicolumn{8}{|l|}{ Cecum } \\
\hline Inflammation & $0(0-1)^{\star}$ & $0(0-0)$ & $3.5(2-4)$ & $\begin{array}{c}4(3-4) \\
P=0.0001^{\ddagger}\end{array}$ & $4(4-4)$ & $\begin{array}{c}4(4-4) \\
P=0.0000^{\S}\end{array}$ & $4(4-4)$ \\
\hline Hyperplasia & $0(0-0)$ & $0(0-0)$ & $3(2-3)$ & $\begin{array}{c}4(3-4) \\
P=0.0001\end{array}$ & $4(4-4)$ & $\begin{array}{c}4(4-4) \\
P=0.0000\end{array}$ & $4(4-4)$ \\
\hline Dysplasia/neoplasia & $0(0-0)$ & $0(0-0)$ & $1(0-2)$ & $\begin{array}{c}3(2-4) \\
P=0.0001\end{array}$ & $3(3-4)$ & $\begin{array}{c}4(2-4) \\
P=0.0000\end{array}$ & $3(2-4)$ \\
\hline $\begin{array}{l}\text { Grade } 3 \text { or } 4 \text { carcinoma } \\
\text { Colon }\end{array}$ & $0 \%(0 / 12)^{\dagger}$ & $0 \%(0 / 7)$ & $0 \%(0 / 8)$ & $94 \%(15 / 16)$ & $100 \%(12 / 12)$ & $88 \%(15 / 17)$ & $91 \%(11 / 12)$ \\
\hline Inflammation & $0(0-0)$ & $0(0-0)$ & $2.5(1-4)$ & $\begin{array}{c}4(2-4) \\
P=0.0001\end{array}$ & $4(4-4)$ & $\begin{array}{c}4(2-4) \\
P=0.0000\end{array}$ & $4(4-4)$ \\
\hline Hyperplasia & $0(0-0)$ & $0(0-0)$ & $2.5(1-4)$ & $\begin{array}{c}4(2-4) \\
P=0.0001\end{array}$ & $4(4-4)$ & $\begin{array}{c}4(2-4) \\
P=0.0000\end{array}$ & $4(4-4)$ \\
\hline Dysplasia/neoplasia & $0(0-0)$ & $0(0-0)$ & $1(0-3)$ & $\begin{array}{c}3(1-3) \\
P=0.0001\end{array}$ & $3(1-3)$ & $\begin{array}{c}3(1-4) \\
P=0.0000\end{array}$ & $3(2-4)$ \\
\hline Grade 3 or 4 carcinoma & $0 \%(0 / 12)$ & $0 \%(0 / 7)$ & $12 \%(1 / 8)$ & $81 \%(13 / 16)$ & $58 \%(7 / 12)$ & $82 \%(14 / 17)$ & $83 \%(10 / 12)$ \\
\hline
\end{tabular}

Inflammation, hyperplasia, dysplasia, and neoplasia were evaluated histologically and scored 0 to 4 as described in the text. Data was subjected to the Mann-Whitney $U$ test by comparison of each criterion of disease in cecum and colon. Data is presented as median score and range. There were significant differences in inflammation, hyperplasia, and dysplasia between infected and uninfected mice at 2 months and 6 months after-infection.

${ }^{*}$ Median score (range).

†Percentage (number affected) grade 3 or grade 4 carcinoma.

¥Mann-Whitney $U$ test, comparison between $H$. hepaticus-infected and sham-dosed Rag2-deficient mice at 2 months after-infection.

$\S$ Mann-Whitney $U$ test, comparison between $H$. hepaticus-infected and sham-dosed Rag2-deficient mice at 6 months after-infection

IL-15 in recipients of T cells. Expression of IL-4 and interferon- $\gamma$ were not detected.

\section{Discussion}

In this study infection with a common mouse enteric bacterial pathogen, $H$. hepaticus, caused colitis in 129/ SvEv Rag-2-deficient mice but not sham-dosed mice. This supported earlier findings that innate immune response was sufficient for chronic inflammation in the lower bowel ${ }^{11,20,21}$ in some strains of mice. H. hepaticusinfected Rag-2-deficient mice developed colitis-associated carcinoma within 4 months after infection, while aged uninfected Rag-deficient mice did not have IBD or cancer, suggesting that helicobacter-driven inflammation promoted carcinogenesis in this model. No dysplasia or carcinoma were observed in wild-type 129/SvEv mice, showing that functional lymphocytes prevented the microbially induced cancer. Adoptive transfer of $\mathrm{CD} 4^{+}$ $\mathrm{CD} 4 \mathrm{RB}^{\text {lo }} \mathrm{CD}^{2} 5^{+} \mathrm{T}$ cells significantly inhibited colitis and cancer in this model. This indicates that lymphocytes may be able to directly inhibit bacterially induced innate immune inflammation, and suggests that regulation of inflammation may be an important function of lymphocytes in preventing cancer in this model.

The lack of inflammation or cancer in aged uninfected 129/SvEv Rag-2-deficient mice in the present study contrasted with previous reports of spontaneous IBD at age 6 months $^{20}$ or carcinoma at age 15 months $^{8}$ in 129/SvEv Rag-2-deficient mice. Shankaran and colleagues ${ }^{8}$ reported that Rag2-deficient mice that developed adeno- carcinoma were free of Helicobacter spp, suggesting that other endogenous bacteria may have similar proinflammatory and carcinogenic potential; however, diverse diets and husbandry practices among animal facilities may also contribute to differences in bowel disease. The lack of cancer in 129 Rag-deficient mice in the work by Engle and colleagues ${ }^{20}$ suggests that complex interactions between microbial and other environmental factors may be required to initiate cancer. Identification of endogenous enteric bacteria other than helicobacter was not specifically done in any of these studies. Analyses are underway in our laboratory using mice infected with Schaedler's defined flora to characterize more definitively how enteric microbiota contribute to intestinal carcinogenesis. ${ }^{39}$

$H$. hepaticus-induced cancer in the present study coincided with the primary sites of colonization of $H$. hepaticus in other inbred strains of mice. ${ }^{40,41}$ The pathogenicity of $H$. hepaticus in this study was not surprising because natural or experimental infection with $H$. hepaticus induced severe typhlocolitis in many immuno-dysregulated mutants; ${ }^{12,41-44} \mathrm{H}$. hepaticus also induced hepatitis-associated liver cancer in some strains of mice. ${ }^{45-47} \mathrm{~A}$ similar progression of chronic inflammation to dysplasia to cancer has been described in $\mathrm{H}$. pylori-induced gastritis and adenocarcinoma in humans. ${ }^{29,48,49}$ In these models, helicobacter-driven dysregulated cell proliferation, demonstrated in the current study with Ki-67 labeling, is proposed to increase cancer risk by increasing the number of cells susceptible to inflammatory-mediated oxidative cellular damage. ${ }^{6,50}$ 

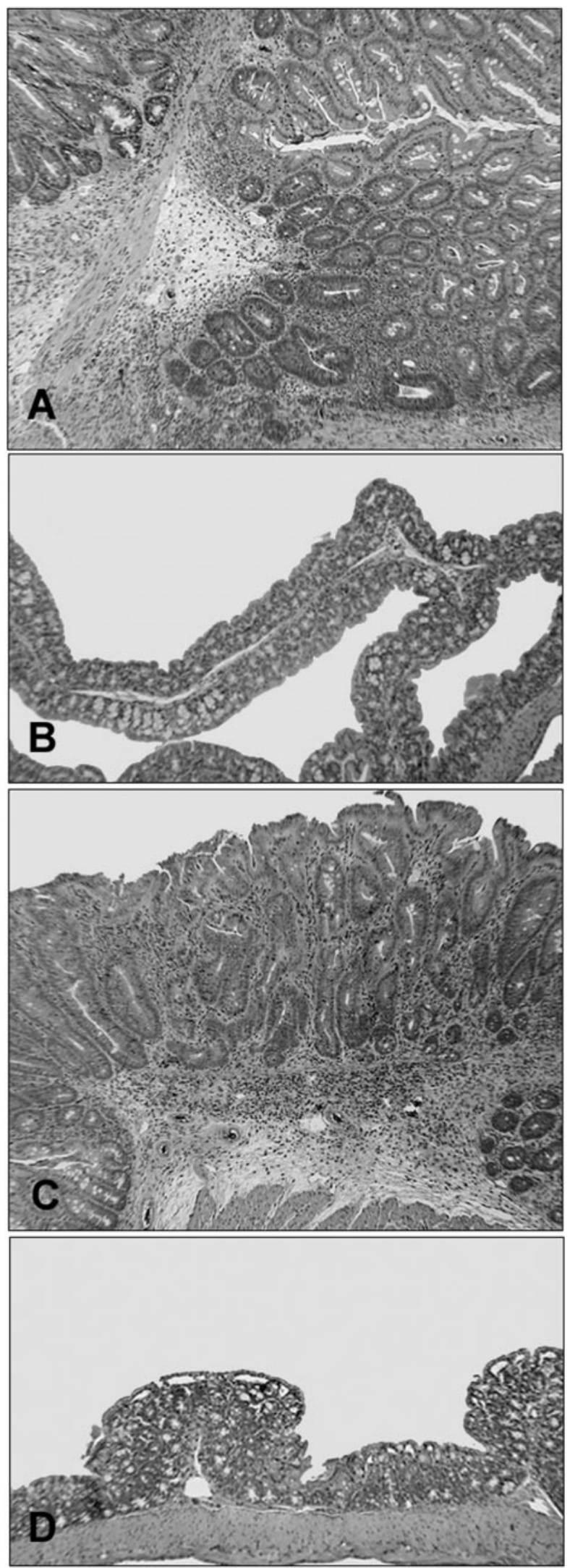

Figure 5. Large bowel histopathology of $H$. hepaticus-infected Rag-2-deficient mice with and without adoptive transfer of $\mathrm{CD}^{+}$regulatory $\mathrm{T}$ cells. Severe inflammation and dysplasia in the cecum $(\mathbf{A})$ and colon $(\mathbf{C})$ in mice that received no regulatory $\mathrm{T}$ cells. Compare with normal histology of cecum $(\mathbf{B})$ and colon $(\mathbf{D})$ in a mouse that received regulatory $\mathrm{T}$ cells. Original magnifications, $\times 40$.
Progression of IBD-associated epithelial dysplasia and carcinoma in these Rag-deficient mice morphologically resembled IBD-associated cancer in other mouse models $^{15,20,35,51,52}$ and the dysplasia sequence of IBD-associated colon cancer in humans. ${ }^{1}$ Carcinoma was locally invasive in these mice, but cancer did not rapidly metastasize to other sites. Among the mouse models of the dysplasia-cancer sequence of IBD in humans, most have failed to develop distant metastases. ${ }^{20,35,51,53}$ Although Rag-deficient mice lack functional lymphocytes, they do have natural killer cells that had characterized anti-metastatic activity in T-cell-deficient mice, ${ }^{54}$ which may help prevent metastases in this model. Helicobacter-infected Rag-2-deficient mice in our facilities remained viable at 8 months after infection suggesting that they may be useful for examining mutations and metastases during aging.

The high frequency of colon cancer in the 129/SvEv Rag-2-deficient mice shown here and previously ${ }^{8,20}$ may be attributable in part to the genetic background of these mice. A similar influence of the 129 strain background on severity of IBD and cancer in IL-10-deficient mice was previously shown by Berg and colleagues. ${ }^{35}$ Recent studies in our laboratory have indicated that $H$. hepaticus induced more severe colitis and epithelial dysplasia in 129/SvEv Rag-2 mice than in BALB/c Rag-deficient or C57BI/6 Rag-deficient mice (data not shown), further supporting that genetic background is important in susceptibility in this model, and indicating that a lymphocyteindependent (innate immune) response to enteric bacteria may be responsible for this strain-related predilection to IBD. This susceptibility of the 129 strain of mice, compared to other strains, may also help explain the discrepancy between our findings and previously reported insensitivity of C57Bl/6 background Rag-deficient mice to H. hepaticus-induced disease. ${ }^{55}$

The observation that wild-type mice did not develop $H$. hepaticus-induced carcinoma suggests that lymphocytes normally maintain homeostasis and prevent bacterially induced cancer in this model. It has been proposed that lymphocytes protect against cancer primarily by locating and eliminating newly arising tumor cells., ${ }^{9,56}$ However, the well-documented ability of $\mathrm{CD} 4^{+} \mathrm{CD} 45 \mathrm{RB}{ }^{\text {lo }}$ or $\mathrm{CD} 4^{+} \mathrm{CD} 25^{+}$regulatory cells to block typhlocolitis induced by $C D 4^{+} C D 45 R B^{\text {hi }}$ effector cells in mice ${ }^{18,19,57}$ indicated that lymphocytes have other critical roles in bowel homeostasis. Our finding that CD45RB ${ }^{10}$ CD25 $5^{+}$ cells were effective in blocking colitis and cancer suggested that T-cell-mediated inhibition of inflammation was central in protecting against cancer in these mice, perhaps in addition to classic immune surveillance. The ability of $\mathrm{CD} 45 \mathrm{RB}^{\mathrm{lo}} \mathrm{CD} 25^{+}$cells to block colitis in the absence of CD45RB ${ }^{\text {hi }}$ or $\mathrm{CD} 25^{-}$effector lymphocytes in this model suggested that these regulatory $T$ cells are able to directly modulate innate immune responses to enteric bacteria. Direct suppression of the innate immune response may be mediated by interactions with activated dendritic cells. ${ }^{19}$ Longer observations after infection will be needed to confirm that this T cell subset truly prevents rather than merely delays onset of $H$. hepaticus-induced cancer. 
Table 2. Comparison of Bowel Disease in $\mathrm{T}$ Regulatory Cell-Treated and Untreated H. hepaticus-Infected Rag-2-Deficient Mice

\begin{tabular}{|c|c|c|c|}
\hline & $\begin{array}{c}\text { Rag-2-deficient pretreated } \\
\text { with CD4+ regulatory cells } \\
\text { with } H \text {. hepaticus } \\
n=17\end{array}$ & & $\begin{array}{c}\text { Rag-2-deficient (controls) } \\
\text { with } H . \text { hepaticus } \\
n=15\end{array}$ \\
\hline & Median score (range) & & Median score (range) \\
\hline \multicolumn{4}{|l|}{ Cecum } \\
\hline Inflammation & $2(0-4)$ & $P<0.0001^{*}$ & $4(3-4)$ \\
\hline Hyperplasia & $1(0-4)$ & $P<0.0001$ & $4(3-4)$ \\
\hline Dysplasia/neoplasia & $1(0-4)$ & $P<0.001$ & $3(2-4)$ \\
\hline \multicolumn{4}{|l|}{ Colon } \\
\hline Inflammation & $2(0-4)$ & $P<0.0001$ & $4(3-4)$ \\
\hline Hyperplasia & $1(0-4)$ & $P<0.0001$ & $4(3-4)$ \\
\hline Dysplasia/neoplasia & $0(0-4)$ & $P<0.001$ & $3(2-4)$ \\
\hline
\end{tabular}

Inflammation, hyperplasia, dysplasia, and neoplasia were evaluated histologically and scored 0 to 4 as described in the text. Data was subjected to the Mann-Whitney $U$ test by comparison of each criterion of disease in cecum and colon. Data is presented as median score and range. There were significant differences in inflammation, hyperplasia, and dysplasia between T-cell-treated and untreated mice.

${ }^{*}$ Mann-Whitney $U$ test, comparison between $H$. hepaticus-infected CD4 ${ }^{+} \mathrm{CD}_{4}$ RB ${ }^{\mathrm{lo}} \mathrm{CD} 25^{+}$regulatory $\mathrm{T}$-cell-treated versus untreated $\mathrm{H}$. hepaticusinfected Rag2-deficient mice.

In this study, 11 of the 17 recipients of regulatory lymphocytes had no or minimal inflammation or dysplasia in the cecum and colon. However, the finding of inflammation and dysplasia in the remaining six recipients of $\mathrm{CD}_{45 \mathrm{RB}}{ }^{\text {lo }} \mathrm{CD}^{2} 5^{+}$cells needs further characterization. One possibility is poor survival or ineffective localization of the highly purified lymphocytes to the intestinal mucosa in those mice; indeed, one of the recipients with IBD had no evidence of $\mathrm{CD}_{4}{ }^{+}$cells in the spleen. It is also possible that other lymphocyte subsets, such as CD25 T cells, are needed for optimal protection against inflammation at this site. ${ }^{19,58,59}$ In addition, the helicobacterfree status and generally low microbial burden of the lymphocyte donors in this study may have reduced the regulatory potency of the transferred lymphocytes. Although it has been previously shown that exposure of donors to enteric bacteria was not required for prevention of colitis in adoptive hosts, ${ }^{19,60}$ a dosage effect was revealed such that inhibitory function of $C D 45 R B^{\text {lo }}$ or $\mathrm{CD}_{25}{ }^{+}$regulatory cells from germ-free donors was im- paired at lower transfer dosages compared with function of cells from donors with enteric microbiota. ${ }^{60}$ Studies are underway in our laboratory to examine these possibilities.

Regulatory T cell inhibition of colitis is mediated at least in part by secretion of IL-10. ${ }^{18,19,59,61,62}$ IL-10 directly counteracts IL-12-driven T helper type (Th) 1 inflammation to maintain homeostasis in the colon. ${ }^{18,19,53,63,64}$ In the present study, CD45RB ${ }^{\text {lo }} \mathrm{CD}^{2} 5^{+} \mathrm{T}$ cells inhibited $H$. hepaticus-induced IL-12 supporting earlier observations that IL-10-mediated suppression of IL-12 significantly determines the extent and severity of $H$. hepaticus-driven colitis. ${ }^{12,13} \mathrm{IL}-10$ was significantly increased in recipients of $\mathrm{CD} 45 \mathrm{RB}^{\text {lo }} \mathrm{CD}^{2} 5^{+} \mathrm{T}$ cells in this study, although the increases were small and the biological significance is unknown. Taken together these data suggest that IL-10 may have a role in cancer prevention in the Rag-deficient model. Indeed, IL-10-deficient mice readily develop IBDassociated colon cancer. ${ }^{35,52}$ An IL-10-mediated mechanism was demonstrated for glial cell tumor rejection in mice ${ }^{65}$ and it was proposed that $\mathrm{CD} 4^{+}$cells directly
IL-12
TNF- $\alpha$
IP-10

IL-6

IL-10

IL-15
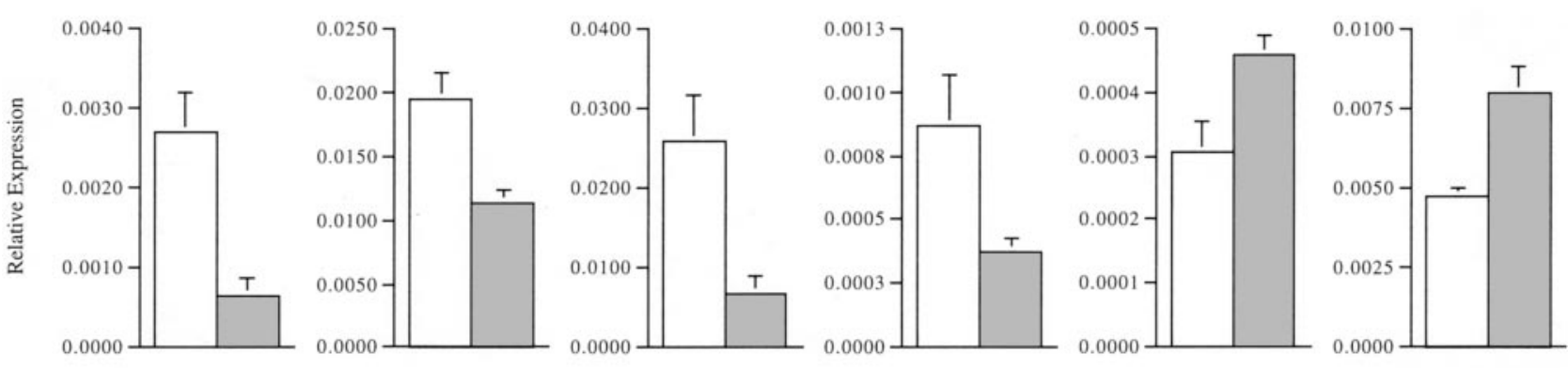

\section{No cells}

\section{$\mathrm{CD}^{+} \mathrm{CD} 45 \mathrm{RB}^{\mathrm{lo}} \mathrm{CD} 25^{+}$}

Figure 6. Adoptive transfer of $\mathrm{CD} 4^{+} \mathrm{CD} 45 \mathrm{RB}^{\mathrm{lo}} \mathrm{CD} 25^{+} \mathrm{T}$ cells suppresses the expression of proinflammatory cytokines tumor necrosis factor- $\alpha$ and IL-12. RNA was isolated from the cecum of $H$. hepaticus-infected Rag-2-deficient mice (open bars) or from Rag-2-deficient mice that received CD ${ }^{+} \mathrm{CD} 45 \mathrm{RB}{ }^{\mathrm{lo}} \mathrm{CD} 25^{+} \mathrm{T}$ cells (hatched bars), before infection. Expression of the indicated genes was analyzed by RNase protection. Intensity of the protected fragments was quantified on a phosphor imager and normalized to GAPDH internal controls. Relative expression is shown on the $y$ axis. Each group consists of five to eight mice with SEM, as indicated. Differences between groups were statistically significant for all cytokines shown $(P<0.05)$. 
suppressed T helper (Th)1-mediated inflammation purported to drive carcinogenesis in that model. Alternatively, it has also been shown that transforming growth factor- $\beta$ was critical in preventing lower bowel cancer in 129/SvEv Rag-2-deficient mice, ${ }^{20}$ although transforming growth factor- $\beta$ has not been directly shown to inhibit $H$. hepaticus-induced inflammation. It remains to be demonstrated whether $\mathrm{CD} 45 \mathrm{RB}^{\mathrm{lo}} \mathrm{CD} 25^{+}$cells require IL-10 or transforming growth factor- $\beta$ to prevent development of colon cancer in the Rag-2-deficient model.

This novel inducible murine model of lower bowel adenocarcinoma enables analysis of the roles of the innate arm as well as the adaptive arm of immunity in the progression of microbially induced colitis and cancer. Targeted induction of carcinogenesis with bacteria permits insertion of lymphocytes before, during, and after malignancy to elucidate mechanisms that promote, prevent, and treat cancer. Adoptive transfer of $\mathrm{CD} 4^{+} \mathrm{CD} 45 \mathrm{RB}^{\text {hi }}$ or CD25- effector T cells will provide a better understanding of the role of T-cell-mediated events and proinflammatory cytokines in the progression of bowel cancer in these mice. Crosses between Rag-deficient mice and other mouse models whose phenotypes mimic human disease may help elucidate immune factors that promote or inhibit bowel cancer. In humans with IBD, colonic dysplasia is a detectable premalignant condition allowing early identification of high-risk cases. By dissecting mechanisms operable in progression of colon carcinogenesis, this mouse model could reveal new strategies for prevention and treatment of human epithelial cell cancers.

\section{Acknowledgments}

We thank Dr. Melanie Ihrig for guidance with statistical analyses, Ms. Elaine Robbins for preparation of figures, and Ms. Jennifer Cline and Ms. Danielle Feldman for technical assistance.

\section{References}

1. Riddell RH, Goldman H, Ransohoff DF, Appleman HD, Fenoglio CM, Haggitt RC, Ahren C, Correa P, Hamilton SR, Morson BC, Sommers SC, Yardley JH: Dysplasia in inflammatory bowel disease: standardized classification with provisional clinical applications. Hum Pathol 1983, 14:931-968

2. Crawford JM (Ed): The Gastrointestinal Tract. Philadelphia, WB Saunders, 1999

3. Fiocchi C: Inflammatory bowel disease: etiology and prevention. Gastroenterology 1998, 115:182-205

4. MacDonald TT, Montelone G, Pender SLF: Recent developments in the immunology of inflammatory bowel disease. Scand J Immunol 2000, 51:2-9

5. Parsonnet J, Friedman GD, Vandersteen DP, Chang Y, Vogelman JH, Orentreich N, Sibley RK: Helicobacter pylori infection and the risk of gastric carcinoma. N Engl J Med 1991, 325:1127-1131

6. Ley C, Parsonnet J (Eds): Gastric Adenocarcinoma. Totowa. Humana Press, Inc., 2000

7. El-Omar EM, Malfertheiner P: Helicobacter pylori and gastric cancer. Curr Opin Gastroenterol 2001, 17(Suppl 1):S24-S27

8. Shankaran V, Ikeda H, Bruce AT, White JM, Swanson PE, Old LJ, Schreiber RD: IFN-gamma and lymphocytes prevent primary tumour development and shape tumour immunogenicity. Nature 2001, 410: $1107-1111$
9. Pardoll D: T cells and tumors. Nature 2001, 411:1010-1012

10. Powrie F: T cells in inflammatory bowel disease: protective and pathogenic roles. Immunity 1995, 3:171-174

11. Cahill RJ, Foltz CJ, Fox JG, Dangler CA, Powrie F, Schauer DB: Inflammatory bowel disease: an immunity-mediated condition triggered by bacterial infection with Helicobacter hepaticus. Infect Immun 1997, 65:3126-3131

12. Kullberg MC, Ward JM, Gorelick PL, Caspar P, Hieny S, Cheever A, Jankovic D, Sher S: Helicobacter hepaticus triggers colitis in specificpathogen-free interleukin-10 (IL-10)-deficient mice through an IL-12and gamma interferon-dependent mechanism. Infect Immun 1998, 66:5157-5166

13. Kullberg MC, Rothfucs AG, Jankovic D, Caspar P, Wynn TA, Gorelick PL, Cheever AW, Sher A: Helicobacter hepaticus-induced colitis in interleukin-10-deficient mice: cytokine requirements for the induction and maintenance of intestinal inflammation. Infect Immun 2001, 69: 4232-4241

14. Iqbal N, Oliver JR, Wagner FH, Lazenby AS, Elson CO, Weaver CT: T helper 1 and $\mathrm{T}$ helper 2 cells are pathogenic in an antigen specific model of colitis. J Exp Med 2002, 195:71-84

15. Kado S, Uchida K, Funabashi H, Iwata S, Nagata Y, Ando M, Onoue M, Matsuoka $\mathrm{Y}$, Ohwaki M, Morotomi M: Intestinal microflora are necessary for development of spontaneous adenocarcinoma of the large intestine in T-cell receptor beta chain and p53 double-knockout mice. Cancer Res 2001, 61:2395-2398

16. Newman JV, Kosaka T, Sheppard BJ, Fox JG, Schauer DB: Bacterial infection promotes colon tumorigenesis in Apc min/+ mice. J Infect Dis 2001, 184:227-230

17. Shinkai Y, Rathbun G, Lam KP, Oltz EM, Stewart V, Mendelsohn M, Charron J, Datta M, Young F, Stall AM: Rag-2 deficient mice lack mature lymphocytes owing to inability to initiate $V(D) J$ chain rearrangement. Cell 1992, 68:855-867

18. Groux H, Powrie F: Regulatory T cells and inflammatory bowel disease. Immunol Today 1999, 20:442-445

19. Singh B, Read S, Asseman C, Malmstrom V, Mottet C, Stephens LA, Stepankova R, Tlaskalova H, Powrie F: Control of intestinal inflammation by regulatory T cells. Immunol Rev 2001, 182:190-200

20. Engle SJ, Hoying JB, Boivin GP, Ormsby I, Gartside PS, Doetschman $\mathrm{T}$ : Transforming growth factor beta-1 suppresses nonmetastatic coIon cancer at an early stage of tumorigenesis. Cancer Res 1999, 59:3379-3386

21. von Freeden-Jeffry U, Davidson N, Wiler R, Fort M, Burdach S, Murray R: IL-7 deficiency prevents development of a non-T cell non-B cellmediated colitis. J Immunol 1998, 161:5673-5680

22. Powrie F, Correa-Oliveira R, Mauze S, Coffman RL: Regulatory interactions between CD45RBhigh and CD45RBlow CD4+ T cells are important for the balance between protective and pathogenic cellmediated immunity. J Exp Med 1994, 179:589-600

23. Groux H, O'Garra A, Bigler M, Rouleau M, Antonenko S, de Vries JE, Roncarolo MG: A CD4+ T-cell subset inhibits antigen-specific T-cell responses and prevents colitis. Nature 1997, 389:737-741

24. Papiernik M: Natural CD4+ CD25+ regulatory T cells: their role in control of superantigen responses. Immunol Rev 2001, 182:180-189

25. Taams LS, Smith J, Rustin MH, Salmon M, Poulter LW, Akbar AN: Human anergic/suppressive CD4+CD25+ T cells: a highly differentiated and apoptosis-prone population. Eur J Immunol 2001, 31: 1122-1131

26. Stephens LA, Mottet C, Mason D, Powrie F: Human CD4+CD25+ thymocytes and peripheral $T$ cells have immune suppressive activity in vitro. Eur J Immunol 2001, 31:1247-1254

27. Read S, Malmstrom V, Powrie F: Cytotoxic T lymphocyte-associated antigen 4 plays an essential role in the function of CD25+CD4+ regulatory cells that control intestinal inflammation. J Exp Med 2000, 192:295-302

28. Maloy K, Powrie F: Regulatory cells in the control of immune pathology. Nature Immunol 2001, 2:816-822

29. Fox JG, Sheppard BJ, Dangler CA, Whary MT, Ihrig M, Wang TC: Germline p53 mutation inhibits Helicobacter-induced premalignant lesions and invasive gastric carcinoma through downregulation of $\mathrm{TH} 1$ proinflammatory responses. Cancer Res 2002, 62:696-702

30. Fox JG, Dewhirst FE, Tully JG, Paster BJ, Yan L, Taylor NS, Collins MJ, Gorelick PL, Ward JM: Helicobacter hepaticus species. nov. a microaerophilic bacterium isolated form livers and intestinal mucosal scrapings from mice. J Clin Microbiol 1994, 32:1238-1245 
31. Fox JG, Yan L, Shames B, Campbell J, Murphy JC: Persistent hepatitis and enterocolitis in germfree mice infected with Helicobacter hepaticus. Infect Immun 1996, 64:3673-3681

32. Shames B, Fox JG, Dewhirst F, Yan L, Shen Z, Taylor NS: Identification of widespread Helicobacter hepaticus infection in feces in commercial mouse colonies by culture and PCR assay. J Clin Microbiol 1995, 33:2968-2972

33. Fox J, Dewhirst FE, Shen Z, Feng Y, Taylor NS, Paster BJ, Ericson RL, Lau CN, Correa P, Araya JC, Roa I: Hepatic Helicobacter species identified in bile and gallbladder from Chileans with chronic cholecystitis. Gastroenterology 1998, 114:755-763

34. Horwitz BH, Scott ML, Cherry SR, Bronson RT, Baltimore D: Failure of Lymphopoiesis after adoptive transfer of NF-kB deficient fetal liver cells. Immunity 1997, 6:765-772

35. Berg DJ, Davidson N, Kuhn R, Muller W, Menon S, Holland G, Thompson-Snipes L, Leach MW, Rennick D: Enterocolitis and colon cancer in interleukin-10-deficient mice are associated with aberrant cytokine production and CD4(+) TH1-like responses. J Clin Invest 1996, 98:1010-1020

36. Schempler RJ, Riddell RH, Kato Y, Borchard F, Cooper HS, Dawsey SM, Dixon MF, Fenoglio-Preiser CM, Flejou JF, Geboes K, Hattori T, Hirota T, Habashi M, Iwafuchi M, Iwashita A, Kim YI, Kirchner T, Klimpfinger M, Koike M, Lauwers GY, Lewin KJ, Oberhuber G, Offner G, Price AB, Ribio CA, Shimizu M, Shimoda T, Sipponen P, Solcia E, Stolte M, Watanabe H, Vamabe H: The Vienna Classification of gastrointestinal epithelial neoplasia. Gut 2000, 47:251-255

37. Hamilton SR, Aaltonen LA: Pathology and genetics of tumors of the digestive system. World Health Organization Classification of Tumors. Lyon, IARC Press, 2000

38. Schempler RJ, Kato Y, Stolte M: Diagnostic criteria for gastrointestinal carcinomas in Japan and Western countries: proposal for a new classification of gastrointestinal epithelial neoplasia. Gastroenterol Hepatol 2000, Oct 15:G49-G57

39. Dewhirst FE, Chien CC, Paster BJ, Ericson RL, Orcutt RP, Schauer DB, Fox JG: Phylogeny of the defined murine microbiota: altered Schaedler flora. App. Environ Microbiol 1999, 65:3287-3292

40. Ge Z, White DA, Whary MT, Fox JG: Fluorogenic PCR-based quantitative detection of a murine pathogen, Helicobacter hepaticus. J Clin Microbiol 2001, 39:2598-2602

41. Whary MT, Cline J, King A, Ge Z, Shen Z, Sheppard B, Fox JG: Long-term colonization levels of Helicobacter hepaticus in the cecum of hepatitis-prone $\mathrm{A} / \mathrm{JCr}$ mice are significantly lower than those in hepatitis-resistant C57BL/6 mice. Comp Med 2001, 51:413-417

42. Ward JM, Anver MR, Haines DC, Melhorn JM, Gorelick P, Yan L, Fox JG: Inflammatory large bowel disease in immunodeficient mice naturally infected with Helicobacter hepaticus. Lab Anim Sci 1996, 46: 15-20

43. Foltz CJ, Fox JG, Cahill R, Murphy JC, Yan L, Shames B, Schauer DB: Spontaneous inflammatory bowel disease in multiple mutant mouse lines: association with colonization by Helicobacter hepaticus. Helicobacter 1998, 3:69-78

44. Erdman SE, Fox JG, Dangler CA, Feldman D, Horwitz BH: Cutting edge: typhlocolitis in NF-kB-deficient mice. J Immunol 2001, 166: 1443-1447

45. Fox JG, Li X, Yan L, Cahill RJ, Hurley R, Lewis R, Murphy JC: Chronic proliferative hepatitis in $\mathrm{A} / \mathrm{JCr}$ mice associated with persistent Helicobacter hepaticus infection: a model of Helicobacter-induced carcinogenesis. Infect Immun 1996, 64:1548-1558

46. Hailey JR, Haseman JK, Bucher JR, Radovsky AE, Malarkey DE, Miller RT, Nyska A, Maronpot RP: Impact of Helicobacter hepaticus infection in B6C3F1 mice from twelve National Toxicology Program two-year carcinogenesis studies. Toxicol Pathol 1998, 26:602-611

47. Ihrig M, Schrenzel M, Fox JG: Differential susceptibility of hepatic inflammation and proliferation in AXB recombinant inbred mice chronically infected with Helicobacter hepaticus. Am J Pathol 1999, 155:571-582

48. Correa P: Human gastric carcinogenesis: a multistep and multifactorial process. First American Cancer Society Award lecture on cancer epidemiology and prevention. Cancer Res 1992, 52:6735-6740

49. Wang T, Dangler CA, Chen D, Goldenring JR, Koh T, Raychowdhury R, Coffey RJ, Ito S, Varro A, Dockray GH, Fox JG: Synergistic interaction between hypergastrinemia and helicobacter infection in a mouse model of gastric cancer. Gastroenterology 2000, 118:36-47

50. Noffsinger AE, Miller MA, Cusi MV, Fenoglio-Preiser CM: The pattern of cell proliferation in neoplastic and nonneoplastic lesions of ulcerative colitis. Cancer 1996, 78:2307-2312

51. Cooper HS, Murthy S, Kido K, Yoshitake H, Flanigan A: Dysplasia and cancer in the dextran sulfate sodium mouse colitis model. Relevance to colitis-associated neoplasia in the human: a study in histopathology, B-catenin and p53 expression and the role of inflammation. Carcinogenesis 2000, 21:757-768

52. Sturlan S, Oberhuber G, Beinhauer BG, Tichy B, Kappel S, Wang J, Rogy MA: Interleukin-10-deficient mice and inflammatory bowel disease associated colon cancer. Carcinogenesis 2001, 22:665-671

53. Rennick DM, Fort MM: Lessons from genetically engineered anima models XII. IL10-deficient mice and intestinal inflammation. Am J Physiol 2000, 278:G829-G833

54. Kundu N, Fulton MA: Interleukin 10 inhibits tumor metastasis, downregulates MHC class 1, and enhances NK lysis. Cell Immunol 1997, 180:55-61

55. Burich A, Hershberg R, Waggie K, Zeng W, Brabb T, Westrich G, Viney JL, Maggio-Price L: Helicobacter-induced inflammatory bowel disease in IL-10- and T cell-deficient mice. Am J Physiol 2001, 281: G764-G778

56. Hung K, Hayashi R, Lafond-Walker A, Lowenstein C, Pardoll D, Levitsky $\mathrm{H}$ : The central role of $\mathrm{CD} 4+\mathrm{T}$ cells in antitumor immune response. J Exp Med 1998, 188:2357-2368

57. Powrie F, Leach W, Mauze S, Menon L, Caddle LB, Coffman RL: Inhibition of Th1 responses prevents inflammatory bowel disease in scid mice reconstituted with CD45RBhi CD4+ T cells. Immunity 1994, 1:553-562

58. Claesson MH, Bregenholt S, Bonhagen K, Stefan T, Moller P, Grusby MJ, Leithauser F, Nissen MH, Reimann J: Colitis-inducing potency of CD4+ T cells in immunodeficient adoptive hosts depends upon their state of activation, IL12 responsiveness, and CD45RB phenotype. J Immunol 1999, 162:3702-3710

59. Kullberg MC, Jankovic D, Gorelick PL, Caspar P, Letterio JJ, Cheever AW, Sher A: Bacteria-triggered CD4+ T regulatory cells suppress Helicobacter hepaticus-induced colitis. J Exp Med 2002, 196:1-13

60. Annacker O, Pimenta-Araujo R, Burlen-Defranoux O, Barbosa TC, Cumano A, Bandiera A: Regulatory CD4 $+\mathrm{T}$ cells control the size of the peripheral activated/memory CD4+ T cell compartment. J Immunol 2000, 164:3537-3580

61. Asseman C, Mauze S, Leach MW, Coffman RL, Powrie F: An essential role for interleukin 10 in the function of regulatory $\mathrm{T}$ cells that inhibit intestinal inflammation. J Exp Med 1999, 190:995-1004

62. Moore KW, de Waal Malefyt R, Coffman RL, O'Garra A: Interleukin-10 and the interleukin-10 receptor. Annu Rev Immunol 2001, 19:683-765

63. Aste-Amezaga M, Ma X, Sartori A, Trinchieri G: Molecular mechanisms of the induction of IL12 and its inhibition by IL10. J Immunol 1998, 160:5936-5944

64. Blumberg RS, Saubermann LJ, Strober W: Animal models of mucosa inflammation and their relation to human inflammatory bowel disease. Curr Opin Immunol 1999, 11:648-656

65. Segal BM, Glass DD, Shevach EM: Cutting edge: IL10-producing CD4+ T cells mediate tumor rejection. J Immunol 2002, 168:1-4 